\title{
Preamble
}

The proposals drafted by Wendy Young and Bill Frelick and reproduced below were written as advocacy pieces, not for publication, the second being provoked by the first. They illustrate dynamically the challenge faced by refugee advocates in responding to interdiction measures: does an alternative to interdiction such as source country processing mitigate the damage done to the right to seek asylum, or does it further undermine the basic principles of refugee protection?

In response to the two contradictory positions, the Refugee Council USA convened a meeting which resulted in a decision to develop a third document that reflects common opposition to current U.S. policies on Haitian asylum seekers.

\section{Resettlement and Processing of Haitian Refugees}

\author{
Wendy Young
}

\begin{abstract}
Political violence and human rights abuses are escalating in Haiti, as the country's nascent democracy deteriorates. Already, the United States and countries in the Caribbean region are developing and implementing policies designed to deter and prevent the arrival of Haitian asylum seekers, despite the fact that the flow of asylum seekers has not yet significantly increased from past years.

This paper raises concerns about the failure of the United States to offer protection to Haitian refugees and proposes the implementation of a resettlement program as a partial solution to this systemic failure. The paper endorses the concept of in-country processing of Haitian refugees if done with significant safeguards to prevent further abuses against such applicants.
\end{abstract}

\section{Résumé}

Alors que la démocratie naissante périclite à Haïti, la violence politique et les abus des droits humains sont en nette croissance. Mais déjà, les États-Unis et d'autres pays de la région des Caraïbes érigent des politiques visant à dissuader et à empêcher l'arrivée de demandeurs d'asile haïtiens, et cela malgré le fait que le flot de réfugiés n'a pas augmenté de façon appréciable par rapport aux années précédentes.

Cet article exprime de fortes inquiétudes devant l'échec des États-Unis à offrir des protections aux réfugiés haïtiens et propose, comme solution partielle à cette défaillance systémique, la mise en ouvre d'un programme de réinstallation. L'article donne son aval à l'idée de traitement sur place des réfugiés haïtiens, à la condition ex- presse que des mesures solides soient mises en place pour garantir la sécurité de tels demandeurs et empêcher qu'ils ne soient victimes d'abus additionnels.

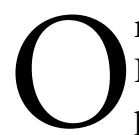
n April 11, 2003, representatives from the White House, Department of Homeland Security, Department of State, the National Coalition for Haitian Rights, the National Immigration Forum, the United States Conference of Catholic Bishops, and the Women's Commission for Refugee Women and Children convened to discuss the need for improved access to U.S. asylum and refugee systems for Haitian asylum seekers. It was requested that the NGO representatives further clarify their recommendations regarding resettlement processing within Haiti itself as well as in countries in the surrounding region, such as the Dominican Republic and the Bahamas.

Before offering a brief outline of the parameters of the proposed resettlement program, we must note that the NGOs providing these recommendations are united in their belief that the United States must comply with its obligations under both U.S. and international law to provide protection to refugees who have a well-founded fear of persecution. Such protection, which would normally be available through the U.S. asylum system, has been severely curtailed for Haitian asylum seekers through a series of measures, despite the deteriorating political and human rights conditions in that country. Such measures have included interdiction, third-country resettlement, detention, denial of parole and bonds, and fast-tracked asylum adjudications.

We therefore offer the following recommendations from the perspective that resettlement is only a partial solution to the barriers preventing Haitians from presenting their asylum claims. 


\section{The Benefits of a Haitian Resettlement System}

\section{In-Country Processing}

In years past, the United States has experienced significant influxes of Haitian refugees when political and economic conditions in Haiti deteriorated. Currently, there is little evidence to justify a fear that we are again facing a Haitian refugee crisis. It is true, however, that human rights conditions in Haiti are worsening. This has resulted in an increase in the asylum grant rate for those Haitians who have been able to access the U.S. asylum system. It has also resulted in a slight increase in the number of Coast Guard interdictions and the numbers of Haitians seeking protection in neighbouring countries such as the Dominican Republic and the Bahamas.

Resettlement processing could serve as an appropriate partial response to this developing situation. It offers an opportunity to balance the fear of a mass outflow against the need to offer protection to Haitians who demonstrate a well-founded fear of persecution. It also would facilitate the ability of the United States to meet its target goal of 50,000 refugee admissions in FY 2003, a goal that is currently eluding the resettlement system in the face of security issues and other concerns in many other parts of the world.

Moreover, resettlement is an orderly process. Unlike asylum, the United States can control the number of refugees brought to the United States. Resettlement also requires thorough security clearances before a refugee is allowed to proceed to the United States. Finally, resettlement would offer an alternative to at least some Haitians who might otherwise attempt the risky boat voyage to the United States.

In-country processing was utilized in Haiti during the 1990s. It offered protection to approximately 1,500 refugees who decided to present themselves at U.S. processing sites. After recognition as refugees, they were allowed to proceed to the United States where they were able to integrate into the United States with the assistance of voluntary agencies with expertise in resettlement.

\section{Regional Processing}

Regional processing out of the Dominican Republic and the Bahamas - the two largest receiving countries for Haitian asylum seekers-would also offer a number of benefits. First, because of their small size and population, both countries have expressed grave concern about the number of Haitians arriving on their shores. Regional resettlement processing would therefore alleviate the pressure on the Dominican Republic and the Bahamas, and would possibly increase the tolerance of the Dominican and Bahamian authorities and public for hosting at least some Haitians.

Second, there is no meaningful refugee protection in either country. Haitians in both countries are vulnerable to detention and forced return. In the Dominican Republic, the Women's Commission has documented that Haitians are vulnerable to police harassment; children are typically deprived of an education; and families often end up homeless and living on the streets of Santo Domingo.

\section{Lessons Learned from Past Resettlement Efforts in the Region}

It must be noted, however, that in-country resettlement processing presents certain risks to would-be applicants. It requires Haitians to surface and present themselves to processing authorities, thus risking exposure to Haitian government authorities and others who might seek to further persecute such applicants. Such incidents were documented in the 1990s, especially in the early days of the program when the only processing site was located across the street from the national headquarters of the Haitian police, who closely monitored, and frequently harassed, individuals seeking access to the processing office.

Resettlement also runs the risk of being burdensome and time consuming. Past in-country processing efforts were hindered by the imposition of multiple in-person interviews that required the applicant to present himself or herself in Portau-Prince. It also required the completion in writing of complex application forms, a requirement that rendered illiterate Haitians virtually ineligible for resettlement.

Finally, once a Haitian was identified as a refugee eligible for resettlement, there were often long delays before the person was actually transferred to the United States. Again, this rendered individuals vulnerable to further persecution while they waited to be moved to the United States.

Following are some measures that must be implemented in the context of any future resettlement program to ensure that such barriers to protection are addressed:

Involvement of U.S.-based and local NGOs with refugee and human rights expertise: The in-country resettlement program initiated in Haiti in the 1990s was significantly improved when U.S.-based resettlement agencies, known as Joint Voluntary Agencies (JVAs), were utilized to identify potential candidates for resettlement and to assist in their processing. In the 1990s, both the U.S. Conference of Catholic Bishops and World Relief acted as JVAs in Haiti. The International Organization for Migration facilitated processing in Port-au-Prince.

Such agencies performed several key functions. They conducted initial screenings and intakes. They assisted Haitians in preparing for their actual refugee interviews. They helped Haitians complete their asylum applications, known as I-589s. They arranged travel for those Haitians accepted for resettlement.

Since that time, several successful initiatives have been implemented to facilitate resettlement in other parts of the 
world that also build upon the expertise of international and local NGOs. For example, in Pakistan, the International Rescue Committee has partnered with local NGOs in an effort to discreetly identify those Afghan refugees most in need of resettlement. In Nairobi, the Hebrew Immigrant Aid Society is working with the UNHCR, relief agencies, and others to identify refugees in the region for whom resettlement is appropriate. By working with local NGOs and others who know the refugee communities, such efforts alleviate the risk of overburdening the processing system with applicants that are clearly ineligible. Such efforts also have precedents in Haiti, as the JVAs frequently took referrals from local human rights organizations.

Location of processing sites: It is critical that processing sites be located not only in Port-au-Prince but in outlying regions as well. In the 1990s, processing sites were eventually set up by the JVAs in Cap Hatien and Les Cayes. This alleviated the need for applicants to make the arduous and often risky trip to the capital in order to access resettlement processing.

Design of processing sites: There are serious risks involved when a Haitian physically appears at a processing site. One potential way to address this concern is by locating processing sites in facilities where other activities are also taking place. Refugee applicants may therefore be less easily identified by anyone monitoring the building. An additional measure that JVAs used in the 1990 s to some effect was to vary the interview sites for applicants. Finally, processing sites should never be located near Haitian government offices.

Community outreach: Individuals in need of resettlement could also be referred to the system without having to present themselves physically at an office. Pilots have been implemented in places such as Pakistan under which Afghan refugees are referred for resettlement through NGOs working at the community level. Again, this would address the potential risk run by the applicant when having to present themselves and at the same time could serve as a useful and effective way to identify those most at risk of persecution.

Streamlining of Interview Procedures: Efforts should be made to limit the number of times an individual is forced to appear in-person to apply for resettlement. In the 1990s, approximately four appearances were required before an applicant was accepted or rejected for resettlement. This was tremendously burdensome to applicants who had to travel each time to the processing site. It also exposed them to further persecution.

Outprocessing: It is also critical that those individuals who are identified as refugees and accepted for resettlement be quickly transferred to the United States. To facilitate this outprocessing, refugee security clearances must be prioritized and conducted quickly.
Regional Processing: Many of the recommendations presented above would also apply to resettlement initiatives in the region. An additional key component would be to facilitate the prompt and safe return to Haiti of those applicants who are found not to qualify for refugee status. This would help ensure that the resettlement program does not become a magnet that prompts more Haitians to attempt to enter the Dominican Republic or the Bahamas.

Prevention of Fraud: Concerns have been raised in past months regarding the vulnerability of refugee resettlement to fraud, as refugees sometimes seek to bring unrelated individuals with them to the United States. Significant groundwork has been laid to address this problem in Africa and other sites through the use biometric data. These efforts should be replicated in any Haitian program.

Minimal Protection for Interdicted Haitians: Even when resettlement is available, there will undoubtedly be some Haitians who choose to leave by boat. The identification of refugees who are interdicted should be facilitated through the assignment of Creole speaking officers on Coast Guard vessels that are patrolling the waters around Haiti. Such officers should at a minimum inquire as to whether an interdicted Haitian has concerns about returning to Haiti. They should also, whenever possible, interview each Haitian individually rather than in groups, so that a refugee can more comfortably raise concerns about returning home. Finally, interdicted Haitians should be informed about the availability of in-country processing if they are repatriated.

\section{Conclusion}

We look forward to discussing these proposals with you in greater detail. While refugee resettlement is only a partial solution toward ensuring adequate protection of Haitian refugees, we believe that it would send an important signal to the world community that the United States will provide protection to at least some Haitians who are victims of human rights abuses.

Cc: Kelly Ryan, Department of State
Scott Busby, Department of State
Lawrence Connell, Department of State
Nancy Iris, Department of State
Molly Groom, Department of Homeland Security

Wendy Young is the Director of Government Relations for the Women's Commission for Refugee Women and Children, a leading U.S.-based research and advocacy organization dedicated to promoting the protection and empowerment of refugee women and children. She is a graduate of Williams College and holds a master's degree and law degree from the American University. 